\title{
中間部材に合板を用いたラージフィンガージョイント 接合部の性能*1
}

\author{
野田康信 $* 2$ ，森 拓郎*3，古田直之*2，小松幸平*3
}

\author{
Study of Large Finger Joint Corner Joints \\ with Applied Plywood Component for Intermediate Member*1
}

\author{
Yasunobu NoDA*2, Takuro MoRI*3, \\ Naoyuki Furuta*2 and Kohei Komatsu*3
}

\begin{abstract}
Wooden frame construction with Large Finger Joints (LFJ) for intermediate member types could be available for middle-rise buildings. The structural performance of this construction would depend on the performance of the intermediate members. In this paper, a plywood laminated component of Karamatsu (Larix kaempferi) was used as the intermediate member. Bending tests of plywood for the vertical direction, shearing tests of plywood and joint efficiency tests of LFJ connecting plywood components with glulam of Karamatsu were conducted to obtain several values to estimate the performance of full scale T-shaped and L-shaped joints. Full scale joint tests showed that the ultimate failure occurred on the LFJ on the plywood component's side. Applying a design method for connections in steel structures to this joint, the estimated strength of the plywood component for shearing was higher than that of LFJ for bending, even though it would have a larger plywood component for heavier timbers. The allowable strength of this joint system could be evaluated from the bending strength of the LFJ of the plywood component.
\end{abstract}

Keywords : rigid joint, glued joint, panel zone, shear strain, plywood.

中層の木質ラーメン構造を実現する方法として, 中間部材挿入型のラージフィンガージョイン ト（LFJ）に着目し，中間部材に構造用合板を積層した部材を用いた場合について検討した。中 間部材の基材となるカラマッ（Larix kaempferi）構造用合板の材料試験，LFJによるカラマッ 構造用集成材との継手性能試験を経て，断面 $150 \times 300 \mathrm{~mm}$ の集成材を用いた L 字形接合部㧍よ びT字形接合部の強度試験を実施した。L字形, T字形試験のいずれにおいても, 終局破壊はす べて中間部材側の LFJ 部の曲げ破壊であった。中間部材の耐力について，鋼構造の接合部パネ ルの評価式を適用して検討した結果，合板表板繊維方向を柱軸方向に対して45傾けて配置した 場合では, 部材断面を大きくした場合においても, 中間部材のせん断降伏が先行しないものと推 測されたことから，本接合法は，LFJの曲げ強度で設計できるという結論に至った。

*1 Received April 30, 2012; accepted August 3, 2012. 本研究の一部は, 日本木材加工技術協会第25回年次大会（2007 年 9 月，旭川），および第10回木質構造研究会技術発表会（2006年11月，東京）において発表した。

*2 北海道立総合研究機構林产試験場 Forest Products Research Institute, Hokkaido Research Organization, Asahikawa 071-0198, Japan

*3 京都大学生存圈研究所 Research Institute for Sustainable Humanosphere, Kyoto University, Uji 611-001, Japan

Corresponding author: Y. Noda (noda-yasunobu@hro.or.jp) 


\section{1. 緒言}

中層建築物を木質フレーム構造で実現するために は，特にその接合部の設計を慎重に行わなくてはな らない。本報は, ラージフィンガージョイント （Large Finger Joint, LFJ）を活用した 3 層程度の 一方向フレームの構築を目指し，その接合部の耐力 について検討したものである。

LFJ とは，フィンガー長さが5 $0 \mathrm{~mm}$ 以上の大型 フィンガーによる接合の総称であり, 大断面集成材 の木口面をフィンガー加工し, 継手や仕口を構成す る接着接合に分類される接合方法の一つである。こ の LFJを用いた構法は, かつて, ビッグフィンガ ージョイント（Big Finger Joint, BFJ）の名称で研 究1-3) が行われ，1992年には継手を対象とした BFJ 設計マニュアルの原案(4) が策定されている。

この LFJ をコーナー接合部に適用する場合には, 梁と柱とを直接接合する直接型と中間部材を介して 接合する中間部材扦入型の 2 種類の仕様がある。新 田ら ${ }^{5,6)}$ によるL字形の接合部試験では, いずれの 仕様に扔いても継手のような接合効率は得られず, 特に, 接合部が開く方向にモーメントが作用した場 合の最大耐力は極端に低く, 破壊は中間部材が瀻維 方向に沿って割裂するといった脆性的なものであっ

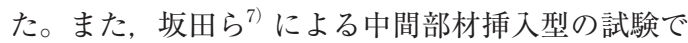
は，仕口角度は $120^{\circ}$ であるが，カラマッ合板を用い た場合の有效性が示唆されている。さらに坂田ら ${ }^{8)}$ は, 中間部材に異方性がなく, 強度の高いものとし てフェノール FRP を採用した場合の実験的研究を 報告している。

一方, 森ら ${ }^{9)}$ はクロスラミナパネル, OSB, 構造 用合板を積層接着した材 (以下，合板積層部材）を 中間部材に採用した場合の耐力を比較検討し，合板 積層部材が有力であることを示した。また，その破 壞形態が LFJ 部の曲げ破壞であった結果を受け， 合板積層部材と集成材の継手性能試験(1) によって, 接合効率を確認した。

本報では，この中間部材に合板積層部材を用いた 場合に着目し, 合板積層部材の曲げ性能, せん断性 能を把握するための材料試験，ならびにLFJ 継手 性能試験から, 実大接合部試験結果を検証し, 鋼構 造に㧍ける接合部耐力推定式の適用を試みた。

\section{2. 実験方法}

\section{1 接合部概要}

本接合部の概要を Fig. 1 に示す。中間部材に合板 積層部材を用いて, これをLFJで集成材を接続す

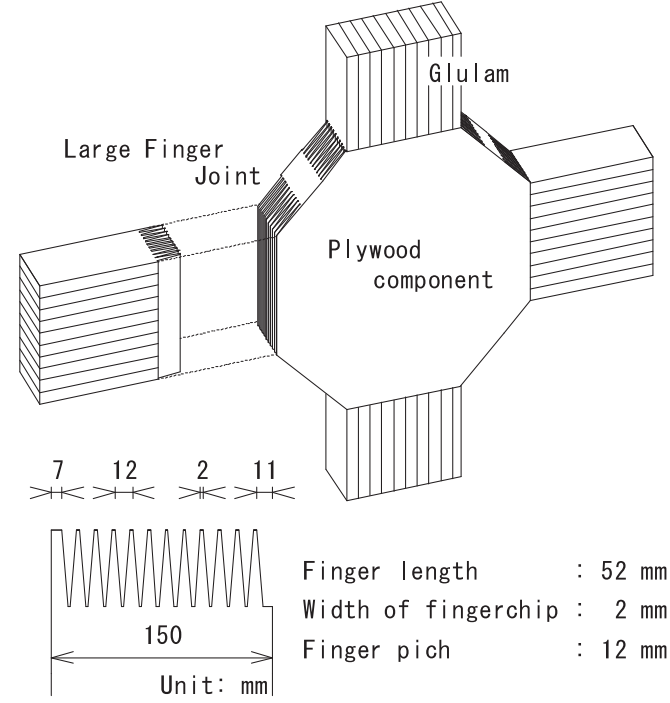

Fig. 1. Joint system and profile of the large finger joint.

ることで一方向のフレーム構面を構築することを想 定する。実験には, 合板積層部材に厚さ $30 \mathrm{~mm}$ の カラマツ (Larix kaempferi) の構造用合板 (910× $2430 \mathrm{~mm}, 2$ 級, 丸玉産業製, 平均気乾密度 $0.56 \mathrm{~g} /$ $\mathrm{cm}^{3}$ ) で, 単板は等厚構成, 積層数は 10 (第 2 層と 第 3 層で同一方向）のものを基材として用いた。こ れを 2 次接着し, 所定の形状に仕上げたものを, LFJ でカラマッ異等級対称構成集成材 (JAS grade E105-F300）と継ぐことでL字形，T字形の実大接 合部を構成した。合板の 2 次接着ならびにLFJ の 嵌合には, レゾルシノール樹脂接着剤（DIC Phenolite6000) を用いた。LFJ は, フィンガー長 さ5 $2 \mathrm{~mm}$ のもの（兼房特注）を用い，切削方向は 材幅方向に対して垂直とし，嵌合した際にフィンガ 一が点対称となるように側面にバット部を設けた (Fig. 1)。直角の接合部の内隅に抢ける応力集中は, フィレット加工で回避でき，等方性体の場合では， その曲率が梁せいの0.49倍で緩和の効果は最大に至 $ろ^{11)}$ が, 本報の仕様では加工の容易性を優先し, 内隅は梁せいの 0.5 倍寸法で直線にカットした。こ のため, 合板積層部材と集成材の接続部には $135^{\circ}$ の 角度が存在するとともに，合板積層部材側で三角錐 のフィンガー未充足部が並列する。

合板積層部材の配置は，表板繊維方向を柱軸方向 と一致させるか, $45^{\circ}$ 傾けるかの 2 択とし, 破壊の クライテリアは, LFJ 部の曲げと中間部材のせん断 とした。接着接合であることから剛節と仮定するこ 
とで, 鋼構造の接合部耐力評価式が適用できると考 えた。

\section{2 合板を縦使いした場合の曲げ性能試験}

合板積層部材の曲げ性能を把握するために，厚さ $30 \mathrm{~mm}$ のカラマツ構造用合板から長さ $480 \mathrm{~mm}$, 断 面 $30 \times 30 \mathrm{~mm}$ に切り出した，スパンに対して表板 纎維方向が $0^{\circ}, 45^{\circ}, 90^{\circ}$ の曲げ試験体（平均気乾密 度 $\left.0.56 \mathrm{~g} / \mathrm{cm}^{3}\right)$ について，スパンをせいの14倍とし た中央集中曲げ試験を, 積層面を縦にして実施した。 これに加え， $0^{\circ}$ 方向については，厚さ $30 \mathrm{~mm}$ のカ ラマツ構造用合板を長手方向に裁断して得た $125 \times$ $2430 \mathrm{~mm}$ 板 4 枚を 2 次接着して, 断面 $120 \times 120$ $\mathrm{mm}$, 長さ $2400 \mathrm{~mm}$ に仕上げた合板積層部材につい て，スパンをせいの 18 倍とした 3 等分 4 点曲げ試験 を, 積層面を縦にして実施した。これらの試験で得 られた最大荷重から最大曲げ応力度 $\sigma_{\max }$ を, 中央 たわみ量と荷重の関係における直線域からヤング係 数 $E$ と比例限曲げ応力度 $\sigma_{\mathrm{pl}}$ を得た。

\section{3 合板の面内せん断試験}

合板積層部材のせん断基本特性を把握するため に, 合板の日本農林規格 ${ }^{12)}$ に準拠したせん断強度

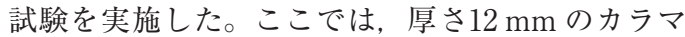
学棈造用合板（等厚単板構成, 積層数 4 , 平均気乾 密度 $0.51 \mathrm{~g} / \mathrm{cm}^{3}$ ) を用い，加力方向に対して表板繊 維方向が $0^{\circ}, 45^{\circ} ， 90^{\circ}$ となるように $910 \times 1820 \mathrm{~mm}$ の合板 5 枚から 1 片ずつ採材した。試験体および試 験方法を Fig. 2 に示す。試験は試験体表裏中央に単 軸ひずみゲージを交差して貼り付けて実施した。試 験で得られた最大荷重から最大せん断応力度 $\tau_{\text {max }}$ を得た。せん断弾性係数 $G$ は, 表裏面の対角線の 圧縮ひずみ, および表裏面の引張ひずみの絶対值の 平均值 $\varepsilon^{\prime}$ と荷重の関係に扮ける直線域から $\gamma=$ $2 \varepsilon^{\prime}, \tau=G \gamma$ の関係より求め, 比例限せん断応力度

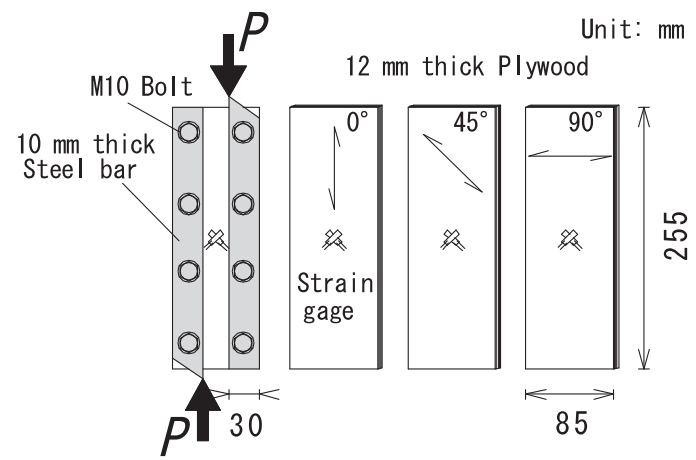

Fig. 2. Shearing test method and specimens. Legend: —: Fiber direction of the surface veneer. $\tau_{\mathrm{pl}}$ を得た。

\section{$2.4 \mathrm{LFJ}$ 継手接合強度試験}

2.2 と同じ方法で製造した断面 $120 \times 120 \mathrm{~mm}$ の合 板積層部材を長さ $450 \mathrm{~mm}$ に切断し, 断面 $120 \times 120$ mm のカラマッ集成材（E105-F300）と LFJ で継 いだものについて，スパンをせいの18倍とした 3 等 分 4 点曲げ試験を実施した (Fig. 3)。その最大曲げ 応力度を 2.2 の結果と比較することで, 合板積層部 材の表板繊維方向を集成材の軸方向に一致させた場 合の接合効率 $\alpha$ を評価した。

\section{5 実大 L 字形接合部試験}

厚さ $30 \mathrm{~mm}$ のカラマツ構造用合板 5 枚を 2 次接 着し， $150 \mathrm{~mm}$ 厚さに仕上げた合板積層部材を中間 部材として，これをLFJ で断面 $150 \times 300 \mathrm{~mm}$ のカ ラマッ集成材（E105-F300）と継ぐことでL字形試 験体とした。合板積層部材の表板繊維方向は集成材 の軸方向に対して $45^{\circ}$ 傾けた。合板積層部材の形状 は, $450 \times 450 \mathrm{~mm}$ の 1 頂点を $45^{\circ}$ で $150 \mathrm{~mm}$ に裁断 して，集成材の断面 $150 \times 300 \mathrm{~mm}$ に対応させた。 試験体と試験方法を Fig. 4 に示す。

見かけの変形角は, 集成材の中心軸の交点を回転 中心とし，そこから $500 \mathrm{~mm}$ 位置のそれぞれの中心 軸線上の 2 点の相対距離を両側から測定し，その平 均值から求めた。試験体数は, 単調引張試験（接合 部が開く方向）で 2 体，単調圧縮試験（接合部が閉 じる方向)で 1 体, 繰り返し荷重試験で 1 体とした。 繰り返し履歴は荷重制御とし, 単調加力試験で得ら れた最大耐力を参考に, 開く方向を正荷重として, 各目標荷重を $+5 \rightarrow-10 \rightarrow+10 \rightarrow-20 \rightarrow+15 \rightarrow-$ $30 \rightarrow+P_{\max } \mathrm{kN}$ と設定した。繰り返し回数は各目標 荷重で 1 回とした。繰り返し荷重試験に供した 1 体 では, Fig. 4 に示す位置に 3 軸のひずみゲージを貼 付して, 表板瀻維方向に対して $0^{\circ}, 90^{\circ}$ ，ならびに $45^{\circ}$ 方向のひずみ分布を計測した。

\section{6 実大 T 字形接合部試験}

合板積層部材を中間部材とし，これをLFJでカ ラマッ集成材（E105-F300）と継ぐことでT字形の

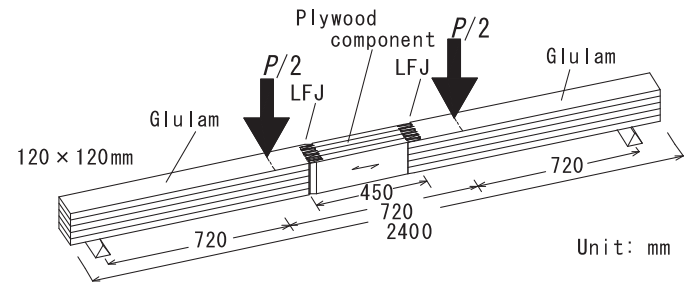

Fig. 3. Specimen for joint efficiency test.

Legend: —: Fiber direction of the surface veneer. 


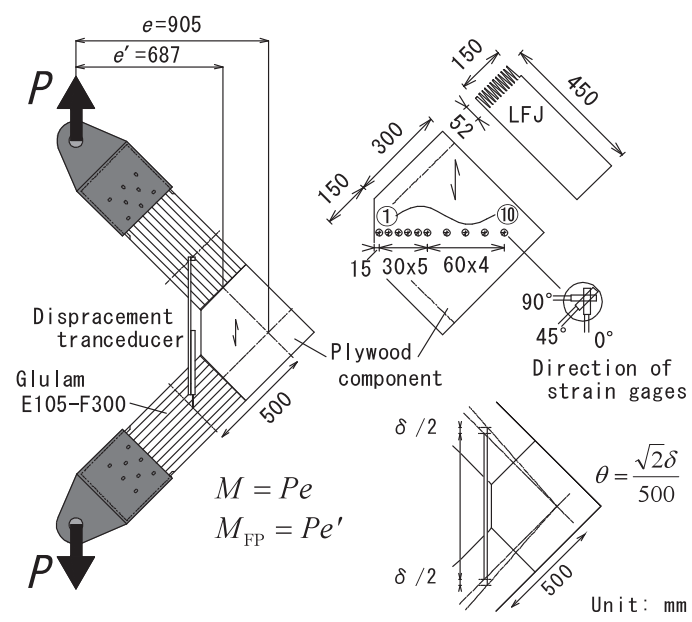

Fig. 4. Setup of L-shaped specimen and definition of moment and rotation angle.

Legend: (1) (10): Number of gage positions, $\longrightarrow$ : Fiber direction of the surface veneer, $M$ : Moment, $e$ : Moment arm of joint performance, $e^{\prime}$ : Moment arm of LFJ part (of the fracture part), $\delta$ : Displacement measured by displacement transducer, $\theta$ : Rotation angle.

接合部を構成し，試験に供した。合板積層部材の表 板繊維方向は鉛直部材の軸方向に一致させ， $600 \times$ $450 \mathrm{~mm}$ の長辺の 2 頂点を $45^{\circ} て ゙ 150 \mathrm{~mm}$ 裁断して, 集成材の断面 $150 \times 300 \mathrm{~mm}$ に対応させた。試験体 および試験方法を Fig. 5 に示す。

見かけの変形角は, 鉛直部材と水平部材の中心軸 の交点を回転中心とし，そこから $500 \mathrm{~mm}$ 位置の中 心軸上の 2 点の相対距離を左裏面と右表面から測定 し, それらの絶対值を平均した值から求めた。試験 体数は 3 体で, 試験は繰り返し荷重方式とした。繰

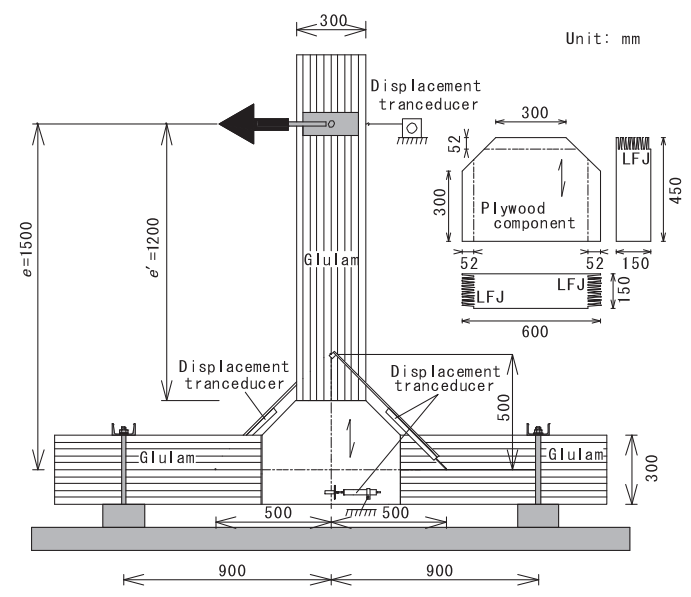

Fig. 5. Setup of T-shaped specimen. Legend: Refer to Fig. 4.

り返し履歴は, 加力点と中間部材の相対水平変位を 加力点から回転中心までの距離で除した縦材の傾き を変形角として，その変形角が $\pm 1 / 300 \rightarrow \pm 1 / 200 \rightarrow$ $\pm 1 / 150 \rightarrow \pm 1 / 100 \rightarrow \pm 1 / 60 \rightarrow \pm 1 / 30 \rightarrow+1 / 15 \mathrm{rad}$ の 正負交番となるように制御した。繰り返し数は各目 標変形角で 3 回とした。

\section{3. 結果と考察}

\section{1 合板を縦使いした場合の曲げ性能}

試験の結果を Table 1 に示す。小試験体の $E$, $\sigma_{\max }, \sigma_{\mathrm{pl}}$ は $45^{\circ}$ 方向で最小であった。 $0^{\circ}$ 方向と $90^{\circ}$ 方向の $\sigma_{\mathrm{pl}}$ は同程度であったが， $E ， \sigma_{\max }$ は $90^{\circ}$ 方 向よりも $0^{\circ}$ 方向の方が小さかった。 $0^{\circ}$ 方向と $90^{\circ}$ 方 向で差が生じる要因は, 単板構成からは考え難いが, 本報では $0^{\circ}$ 方向の值を採用して考察を進める。

Table 1. Bending performance of plywood for vertical direction and joint efficiency connected with glulam using LFJ.

\begin{tabular}{|c|c|c|c|c|c|c|c|c|c|c|c|c|c|}
\hline \multirow{2}{*}{ Test } & \multirow{2}{*}{$\begin{array}{l}\text { Span } \\
(\mathrm{mm})\end{array}$} & \multirow{2}{*}{$\begin{array}{c}\text { Cross } \\
\text { section } \\
\text { size }(\mathrm{mm})\end{array}$} & \multirow{2}{*}{ Angle $^{c)}$} & \multirow{2}{*}{$\begin{array}{l}\text { Number } \\
\text { of } \\
\text { specimen }\end{array}$} & \multicolumn{2}{|c|}{$E\left(\mathrm{kN} / \mathrm{mm}^{2}\right)$} & \multicolumn{3}{|c|}{$\sigma_{\max }\left(\mathrm{N} / \mathrm{mm}^{2}\right)$} & \multicolumn{3}{|c|}{$\sigma_{\mathrm{pl}}\left(\mathrm{N} / \mathrm{mm}^{2}\right)$} & \multirow[t]{2}{*}{$\varepsilon_{\mathrm{pl}}(\mu \varepsilon)$} \\
\hline & & & & & Ave. & C.V. & Ave. & C.V. & 5\%ile & Ave. & C.V. & 5\%ile & \\
\hline \multirow{3}{*}{$\begin{array}{c}\text { Small } \\
\text { bendinga) }\end{array}$} & \multirow{3}{*}{420} & \multirow{3}{*}{$30 \times 30$} & $0^{\circ}$ & 12 & 5.3 & $6.9 \%$ & 33.0 & $20.6 \%$ & 19.1 & 19.0 & $1.9 \%$ & 18.3 & 3453 \\
\hline & & & $45^{\circ}$ & 6 & 1.8 & $2.7 \%$ & 18.6 & $4.8 \%$ & 16.5 & 12.0 & $2.8 \%$ & 11.2 & 6222 \\
\hline & & & $90^{\circ}$ & 8 & 6.9 & $7.1 \%$ & 49.6 & $11.0 \%$ & 37.6 & 18.9 & $2.3 \%$ & 17.9 & 2594 \\
\hline $\begin{array}{c}\text { Beam } \\
\text { bending }\end{array}$ & 2160 & $120 \times 120$ & $0^{\circ}$ & 5 & 5.3 & $6.3 \%$ & $23.8(\mathrm{~A})$ & $10.6 \%$ & 17.6 & 21.0 & $11.9 \%$ & 14.8 & $\begin{array}{c}\text { Joint } \\
\text { efficiency }\end{array}$ \\
\hline $\begin{array}{c}\text { Joint } \\
\text { efficiency }\end{array}$ & 2160 & $120 \times 120$ & $0^{\circ}$ & 5 & - & - & $20.4(\mathrm{~B})$ & $10.5 \%$ & 15.1 & 20.1 & $11.4 \%$ & 14.5 & $\begin{array}{c}\mathrm{B} / \mathrm{A}= \\
0.86\end{array}$ \\
\hline
\end{tabular}

a) 3 point bending, ${ }^{\text {b) }}: 4$ point bending, ${ }^{c}$ : Fiber direction of surface veneer to loading direction.

Legend: $E$ : Young's modulus, $\sigma_{\max }$ : Bending strength, $\sigma_{\mathrm{pl}}$ : Proportional limit strength, $\varepsilon_{\mathrm{pl}}$ : Proportional limit bending strain $=\sigma_{\text {pl_5\%ile }} / E_{\text {Ave }}$, Ave. : Average, C.V.: Coefficient of variation, $5 \%$ ile : Fifth percentile lower limit of normal distribution. 
断面 $120 \times 120 \mathrm{~mm}$ の 3 等分 4 点曲げ試験の破壊 形態は脆性的であり, $\sigma_{\max }$ と $\sigma_{\mathrm{pl}}$ の平均值の差は, 小試験体の $0^{\circ}$ 方向の場合とくらべて小さかった。 $\sigma_{\max }$ の正規分布仮定による信頼水準 $75 \%$ の $95 \%$ 下 側許容限界值（以下， $5 \%$ 下限值）は, 小試験体の $0^{\circ}$ 方向の $\sigma_{\max }$ の $5 \%$ 下限值よりも小さく, 小試験 体の $0^{\circ}$ 方向の $\sigma_{\mathrm{pl}}$ の $5 \%$ 下限值に近い值であった。 これらのことから, 実大の曲げ強度特性值には小試 験体の $\sigma_{\mathrm{pl}}$ の $5 \%$ 下限值が対応するものと考え, 以 下の考察では, $0^{\circ}$ 方向と $45^{\circ}$ 方向の実大の曲げ強度 特性值に, それぞれ $\sigma_{0}=18.3 \mathrm{~N} / \mathrm{mm}^{2}, \quad \sigma_{45}=11.2 \mathrm{~N} /$ $\mathrm{mm}^{2}$ を採用する。また, 比例限引張ひずみ量 $\varepsilon_{\mathrm{pl}}$ を ヤング係数と曲げ応力度との関係 $\varepsilon_{\mathrm{pl}}=\sigma_{\mathrm{pl} \_5 \% \text { ile }} / E_{\text {ave }}$ より算出したところ, $45^{\circ}$ 方向が最も大きい值であ った (Table 1)。

\section{2 合板の面内せん断性能}

試験の結果を Table 2 に示す。高見 ${ }^{13)}$ の報告と 同様に, $45^{\circ}$ 方向の $G, \tau_{\max }, \tau_{\mathrm{pl}}$ は, $0^{\circ}, 90^{\circ}$ 方向 に比べて大きかった。 $0^{\circ}$ 方向と $90^{\circ}$ 方向の差は小さ く，ばらつきの範囲とみなせるが，ここでは $0^{\circ}$ 方 向と $45^{\circ}$ 方向の $\tau_{\mathrm{pl}}$ の $5 \%$ 下限值をせん断強度特性 值 $\tau_{0}=2.09 \mathrm{~N} / \mathrm{mm}^{2}, \tau_{45}=4.78 \mathrm{~N} / \mathrm{mm}^{2}$ として採用 する。また, 比例限せん断ひずみ量 $\gamma_{\mathrm{pl}}$ をせん断弾 性係数とせん断応力度の関係 $\gamma_{\mathrm{pl}}=\tau_{\mathrm{pl}} / G_{\mathrm{ave}}$ より算出 して Table 2 に併記した。ここで, せん断変形にお ける対角線の比例限ひずみ量 $\varepsilon_{\mathrm{pl}}^{\prime}$ は $\gamma_{\mathrm{pl}} / 2 て ゙ あ り$, $45^{\circ}$ 方向での計算值 $653 \mu \varepsilon$ は, 表板繊維 $0^{\circ}$ 方向, も しくは90方向の伸縮である。この值は, Table 1 の $0^{\circ}$ 方向, $90^{\circ}$ 方向の比例限引張ひずみ量よりも小 さかった。

\subsection{LFJ 継手接合強度}

破壊はすべて，合板積層部材側の継手の根元にお ける曲げ破壊であった。試験結果を Table 1 に示す。 この曲げ強度と 3.1 で得た断面 $120 \times 120 \mathrm{~mm}$ の曲げ 強度との比は, 平均值同士による場合と $5 \%$ 下限值 同士による場合のいずれにおいても0.86あった。こ
こでは，この比が任意の角度においても適用できる ものと仮定して, 接合効率 $\alpha$ として採用する。すな わち, 合板積層部材の LFJ 曲げ強度 $\sigma_{\mathrm{LFJ}}$ は, $\sigma_{0}$, $\sigma_{45}$ に $\alpha=0.86$ を乗じて, $\sigma_{0 \_\mathrm{LFJ}}=15.7 \mathrm{~N} / \mathrm{mm}^{2}, \sigma_{45 \_\mathrm{LFJ}}$ $=9.6 \mathrm{~N} / \mathrm{mm}^{2}$ として以下の考察で用いる。

なお, 今回の両者の曲げ強度のばらつきは同程度 で，平均值と $5 \%$ 下限值の $\alpha$ が同じであったが，通 常は，スモールフィンガーの場合 ${ }^{14)}$ と同じく，母 材の曲げ強度のばらつきに比べて, フィンガージョ イント材の曲げ強度のばらつきは小さく, $5 \%$ 下限 值による $\alpha$ りも平均值による $\alpha$ の方が小さくなる ものと考えられる。したがって，設計においては平 均值による接合効率を用いた方が安全であると考え られる。

\section{4 実大 $\mathrm{L}$ 字形接合部試験}

モーメント $M(=P \times e)$ と見かけの変形角 $\theta$ の 関係図を Fig. 6 に，試験結果を Table 3 に示す。開 く方向よりも閉じる方向で最大モーメント $M_{\max }$ が 大きかったが，既往 ${ }^{5,6)}$ の集成材を中間部材とした 場合にくらべて，開閉の差は小さかった。完全弾塑

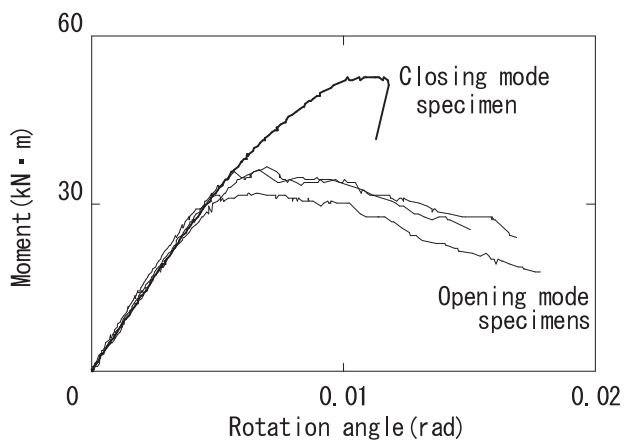

Fig. 6. Moment and rotation angle curve of L-shaped specimens.

Note: Result of the L-shaped specimen for closing mode failure was evaluated as an absolute value and was shown on the first quadrant.

Table 2. Shearing performance of plywood.

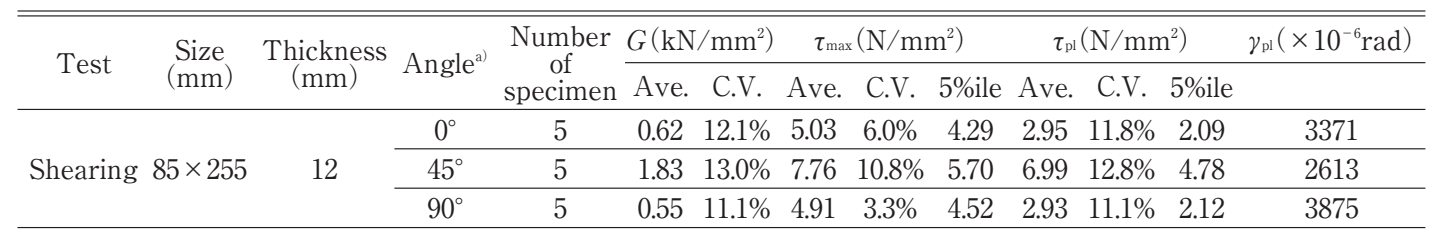

\footnotetext{
a) : Fiber direction of surface veneer to loading direction.
}

Legend: $G$ : Shear modulus, $\tau_{\max }$ : Shear strength, $\tau_{\mathrm{pl}}$ : Proportional limit strength, $\gamma_{\mathrm{pl}}$ : Proportional limit shear strain $=\tau_{\text {pı_5\%ile }} / G$, Ave. : Average, C.V.: Coefficient of variation, $5 \%$ ile : Fifth percentile lower limit of normal distribution. 
Table 3. Results of L-shaped specimens.

\begin{tabular}{ccccccccccc}
\hline \hline Specimen & $\begin{array}{c}K \\
(\mathrm{kN} \cdot \mathrm{m} / \mathrm{rad})\end{array}$ & $\begin{array}{c}M_{\max } \\
\mathrm{kN} \cdot \mathrm{m})\end{array}$ & $\begin{array}{c}2 / 3 M_{\max } \\
(\mathrm{kN} \cdot \mathrm{m})\end{array}$ & $\begin{array}{c}M_{\mathrm{pl}} \\
(\mathrm{kN} \cdot \mathrm{m})\end{array}$ & $\begin{array}{c}M_{\mathrm{y}} \\
(\mathrm{kN} \cdot \mathrm{m})\end{array}$ & $\mu$ & $\begin{array}{c}M_{\mathrm{FP}} \\
(\mathrm{kN} \cdot \mathrm{m})\end{array}$ & $\begin{array}{c}M_{\mathrm{FP}, \mathrm{pl}} \\
(\mathrm{kN} \cdot \mathrm{m})\end{array}$ & $\begin{array}{c}\sigma_{\mathrm{FP}} \\
\left(\mathrm{N} / \mathrm{mm}^{2}\right)\end{array}$ & $\begin{array}{c}\sigma_{\mathrm{FP}} \mathrm{pl} \\
\left(\mathrm{N} / \mathrm{mm}^{2}\right)\end{array}$ \\
\hline L_Open1 & 6909 & 36.7 & 24.4 & 33.3 & 20.6 & 2.76 & 28.0 & 22.9 & 12.4 & 10.2 \\
L_Open2 & 7398 & 32.0 & 21.3 & 29.1 & 20.0 & 3.02 & 24.4 & 20.0 & 10.8 & 8.9 \\
L_Open3 & 6672 & 36.2 & 24.1 & 23.9 & 23.0 & 2.50 & 27.6 & 16.4 & 12.3 & 7.3 \\
\hline Ave. & 6993 & 34.9 & 23.3 & 28.8 & 21.2 & 2.76 & 26.7 & 19.8 & 11.9 & 8.8 \\
C.V. & $5.3 \%$ & $7.4 \%$ & $7.4 \%$ & $16.4 \%$ & $7.4 \%$ & $9.5 \%$ & $7.4 \%$ & $16.4 \%$ & $7.4 \%$ & $16.4 \%$ \\
5\%ile & 5825 & 26.8 & 17.9 & 13.9 & 16.2 & 1.94 & 20.4 & 9.6 & 9.1 & 4.3 \\
\hline L_Close & 6485 & 52.7 & 35.1 & 34.3 & 32.3 & 1.55 & 40.2 & 23.6 & 17.9 & 10.5 \\
\hline
\end{tabular}

Legend : $K$ : Rotational rigidity, $M$ : Moment, $\mu$ : Ductility factor, $\sigma$ : Bending stress, Ave. : Average, C.V. : Coefficient of variation, $5 \%$ ile : Fifth percentile lower limit of normal distribution.

Subscript: $\max$ : Maximum, pl: Proportional limit, y: Yield, FP : Fracture position.

Note: $M_{\mathrm{y}}$ and $\mu$ were conducted with bi-liner model analysis.

性モデルによる評価 ${ }^{15)}$ では, 開く方向の塑性率 $\mu$ が大きかった。開く方向に扔いて，降伏モーメント $M_{\mathrm{y}}$ は $2 / 3 M_{\max }$ と同程度であった。

破壊箇所となった LFJ 位置において, モーメン トアーム $e^{\prime}$ (Fig. 4) とした存在モーメント $M_{\mathrm{FP}}(=$ $\left.P \times e^{\prime}\right)$ より $\sigma=M / Z$ の関係から, 解析断面を 150 $\times 300 \mathrm{~mm}$ として曲げ破壊応力 $\sigma_{\mathrm{FP}}$ を算出したとこ 万, 開く方向に抒いては平均值で $\sigma_{45 \text { LIFJ }}$ を上回るが 5 \%下限值で下回った。また, このモーメントの比 例限 $M_{\mathrm{FP}-\mathrm{pl}}$ から算出した曲げ破壊応力 $\sigma_{\mathrm{FP}, \mathrm{pl}}$ は, 平 均值, $5 \%$ 下限值ともに $\sigma_{45}$ _LFJ を下回った。一方, 閉じる方向の $\sigma_{\mathrm{FP}}$ は開く方向よりも高く， $\sigma_{\mathrm{FP}-\mathrm{pl}}$ は $\sigma_{45 \_L F J}$ 相当であった。

開く方向の破壊形態を Fig. 7 に示す。内隅のフィ ンガー未充足部は断面欠損であるため，ここで初期 破壊が生じたことにより， $\sigma_{\mathrm{FP} \text { _pl }}$ は $\sigma_{45 \_\mathrm{LFJ}}$ を下回っ たと考えられる。その後, 最弱の $45^{\circ}$ 方向に沿って 集成材軸方向に裂けてから, 終局破壊断面である集 成材の梁せい方向で曲げ破壞し, 終局に至ったと考 える。このように 2 段階に割裂方向が変化したこと により，延性的な性状を示し， $\sigma_{\mathrm{FP}}$ は $\sigma_{45 \_\mathrm{LFJ}}$ を上回 ったものと推察する。

閉じる方向の破壊性状を Fig. 8 に示す。合板積層 部材側フィンガーの根元で初期破壊し, LFJ 面に沿 って曲げ破壊して終局に至った。初期破壊で降伏し たものと考えれば $\sigma_{\mathrm{FP} \_\mathrm{pl}}$ が $\sigma_{45 \text { _LFJ }}$ 相当であったこと と一致する。その後, 終局破壊に至るまでに延性的 な破壊性状を示した理由としては，L字形の頂部側 最外皮の応力は中間部材の領域では応力分散効果が 得られるためと考える。最外皮で表板繊維 $45^{\circ}$ 方向 に生じていた応力は, 中間部材の領域に入ると頂点 が無応力状態であることから, 主応力方向が表板繊 維 $0^{\circ}$ 方向へとシフトしていることが考えられる。

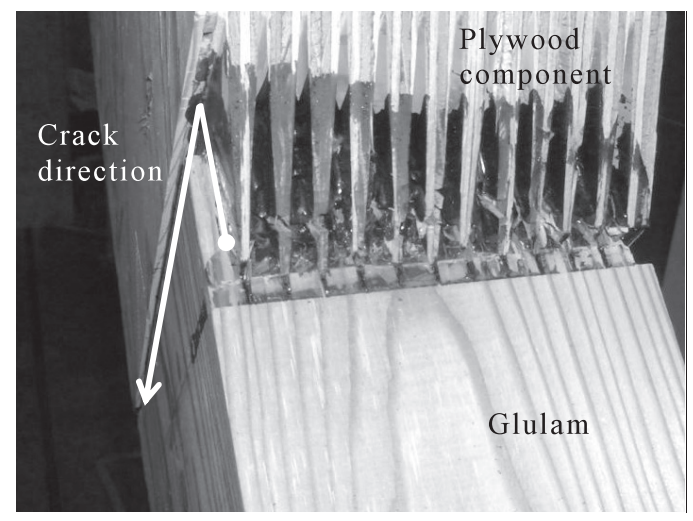

Fig. 7. Ultimate failure of L-shaped specimen in opening mode.

Note: There are triangular pyramidal voids of finger joint inside of plywood component. The crack emanated at the fingertips of the plywood component. The crack progressed in the 45 degree direction of the plywood component into the finger root of the plywood component. The crack direction turned at the finger root toward the glulam depth direction.

Fig. 9 にL_Open3 で測定した開く方向における $0^{\circ}, 90^{\circ}$, ならびに $45^{\circ}$ 方向のひずみ分布の実測值を $10 \mathrm{kN} \cdot \mathrm{m}$ 毎に示す。個々のゲージ值は $0^{\circ}$ 方向, $90^{\circ}$ 方向では, ゲージ1 1)除いて $30 \mathrm{kN} \cdot \mathrm{m}$ まではモー メントと比例関係にあった。頂部に向かってひずみ は小さく, 内隅側では $0^{\circ}$ 方向は引張ひずみ, $90^{\circ}$ 方 向は圧縮ひずみとなっている。

ここで， $0^{\circ}$ 方向と $90^{\circ}$ 方向のひずみ量の平均值が $45^{\circ}$ 方向のひずみ量に相当していたことから, $0^{\circ}$ 方 向と $90^{\circ}$ 方向を主ひずみ方向とみなし, $0^{\circ}$ 方向と $90^{\circ}$ 方向のひずみ量は曲げ応力とせん断応力に由来する 


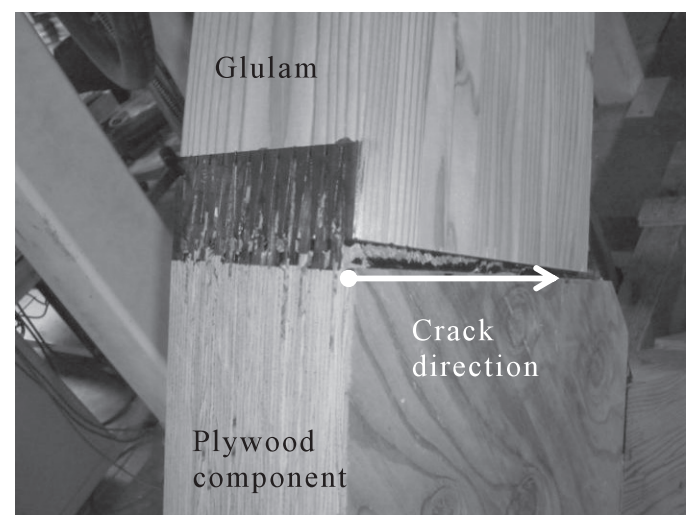

Fig. 8. Ultimate failure of L-shaped specimen in the closing mode.

Note: The crack emanated at the finger roots of the plywood component and progressed in the glulam depth direction.

複合応力によるひずみ量であると仮定する。まず, $0^{\circ}$ 方向の (1)(2)のひずみに注目する。内隅最内皮にお けるせん断応力は 0 であるため, 内隅側では曲げ応 力が支配的と考えて妥当である。ゲージ1は最大ひ ずみ量まではモーメントと比例関係にあり， $0^{\circ}$ 方向

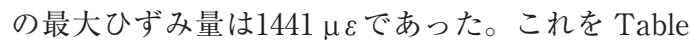
1 の $E_{0}$ より応力に換算すると $7.6 \mathrm{~N} / \mathrm{mm}^{2}$ であり, L_Open3 の比例限応力度 $\sigma_{\mathrm{FP} \text { _pl }}$ に相当する值であっ た。また, $30 \mathrm{kN} \cdot \mathrm{m}$ 時点で(2)が最大となったのは, フィンガー未充足部の初期破壊の発生後に, 内隅最 内皮で伝達していた応力が頂部側にシフトしていっ た表れと考える。この応力の再分配が延性的な破壊 性状に貢献したと考えている。

次にせん断ひずみについて，ゲージ(5)(6)(7)に注 目して考察する。合板積層部材内における曲げ応力 の中立軸は不明であるが，ひずみを計測した断面に おいては， $45^{\circ}$ 方向のひずみ量が 0 である近辺に曲
げ応力の中立軸が存在するものと考えれば, (5)から (8)間に純せん断となる微小要素が存在しているも のと考えられる。9 $90^{\circ}$ 方向のひずみ量は, 厳密には 曲げによって $0^{\circ}$ 方向で圧縮応力となる領域に扔い ては，ポアソン比から $90^{\circ}$ 方向の引張ひずみ量が加 算されていることになるが，すべてをせん断由来の ものとみなすことは, 最も不利な評価であると考え

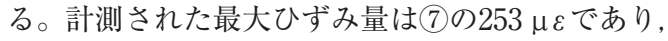
これを純せん断によるひずみの最大值とみなして,

Table 2 の $G_{45}$ よりせん断応力に換算すると $0.92 \mathrm{~N} /$ $\mathrm{mm}^{2}$ である。この值は, Table 2 の $45^{\circ}$ 方向の $\tau_{\mathrm{pl}}$ よ りも小さいことから, 接合部パネルは降伏していな いものと考えられる。

\section{$3.5 \mathrm{~T}$ 字形接合部試験}

$M$ と $\theta$ の関係を Fig. 10に, 特性值を Table 4 に 示す。回転剛性 $K$ は L 字形と比べて大きかったが, これは片側の水平部材のモーメント負担割合の違い によるものと考える。鉛直部材の破壊点における最

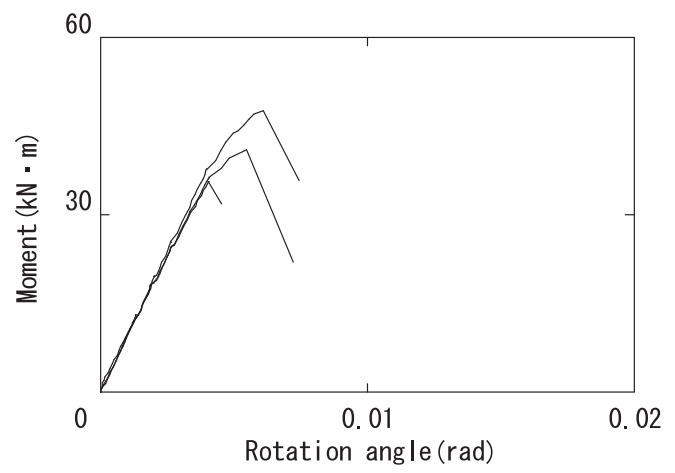

Fig. 10. Moment and rotation angle curve of T-shaped specimens.

Note: The angle is the average calculated from the absolute values of displacement on both sides (Refer to Fig. 5).
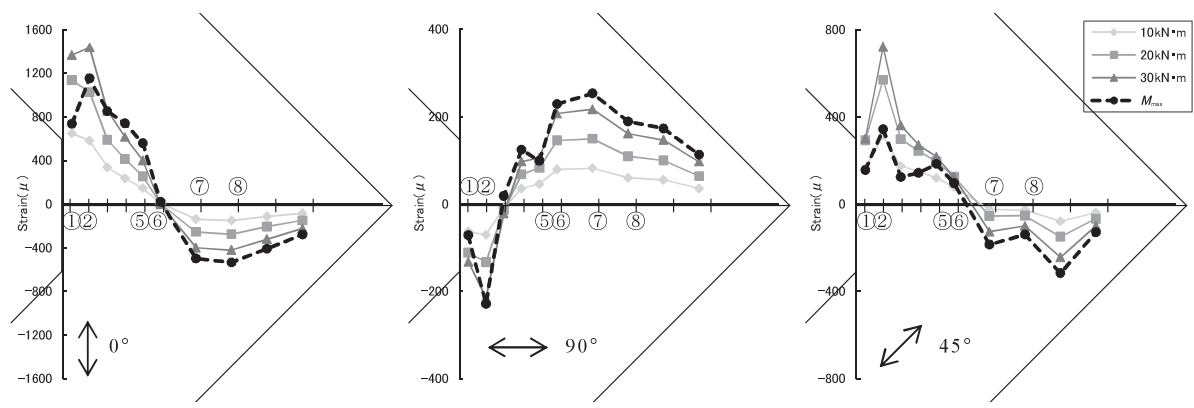

Fig. 9. Strain distribution for $0^{\circ}, 90^{\circ}$ and $45^{\circ}$ directions of the surface veneer's fiber on particular moment level.

Legend: (1) (10): Refer to Fig. 4, $M_{\max }$ : At maximum moment. 
Table 4. Results of T-shaped specimens.

\begin{tabular}{ccccccccccc}
\hline \hline Specimen & $\begin{array}{c}K \\
(\mathrm{kN} \cdot \mathrm{m} / \mathrm{rad})\end{array}$ & $\begin{array}{c}M_{\max } \\
(\mathrm{kN} \cdot \mathrm{m})\end{array}$ & $\begin{array}{c}2 / 3 M_{\max } \\
(\mathrm{kN} \cdot \mathrm{m})\end{array}$ & $\begin{array}{c}M_{\mathrm{pl}} \\
(\mathrm{kN} \cdot \mathrm{m})\end{array}$ & $\begin{array}{c}M_{\mathrm{y}} \\
(\mathrm{kN} \cdot \mathrm{m})\end{array}$ & $\mu$ & $\begin{array}{c}M_{\mathrm{FP}} \\
(\mathrm{kN} \cdot \mathrm{m})\end{array}$ & $\begin{array}{c}M_{\mathrm{FP} p \mathrm{pl}} \\
(\mathrm{kN} \cdot \mathrm{m})\end{array}$ & $\begin{array}{c}\sigma_{\mathrm{FP}} \\
\left(\mathrm{N} / \mathrm{mm}^{2}\right)\end{array}$ & $\begin{array}{c}\sigma_{\mathrm{FP}} \mathrm{pl} \\
\left(\mathrm{N} / \mathrm{mm}^{2}\right)\end{array}$ \\
\hline T_01 & 8847 & 41.0 & 27.3 & 36.3 & 31.6 & 1.22 & 32.8 & 29.0 & 14.6 & 12.9 \\
$\mathrm{~T} \_02$ & 9910 & 47.6 & 31.7 & 37.7 & 30.1 & 1.27 & 38.1 & 30.2 & 16.9 & 13.4 \\
T_03 & 9233 & 35.6 & 23.7 & 35.6 & 25.6 & 1.18 & 28.5 & 28.5 & 12.7 & 12.7 \\
\hline Ave. & 9330 & 41.4 & 27.6 & 36.5 & 29.1 & 1.22 & 33.1 & 29.2 & 14.7 & 13.0 \\
C.V. & $5.8 \%$ & $14.5 \%$ & $14.5 \%$ & $2.9 \%$ & $10.7 \%$ & $3.7 \%$ & $14.5 \%$ & $2.9 \%$ & $14.5 \%$ & $2.9 \%$ \\
5\%ile & 7634 & 22.5 & 15.0 & 33.2 & 19.3 & 1.08 & 18.0 & 26.5 & 8.0 & 11.8 \\
\hline
\end{tabular}

Note: Refer to Table 3.

大モーメント $M_{\mathrm{FP}}$ はL 字形よりも大きかった。こ のことは, 合板積層部材の表板繊維方向を鉛直部材 軸方向に一致させたことによるものと考えられる。

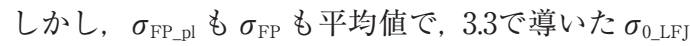
を下回る結果であった。

終局破壊は，開く方向となった鉛直部材の LFJ 部での曲げ破壊で，合板積層部材側のフィンガーか らの破断（Fig. 11）であるが, 初期破壊はL字形と 同じく, 内隅のフィンガー未充足部で生じたため, $\sigma_{\mathrm{FP} \_\mathrm{pl}}$ が $\sigma_{0 \_\mathrm{LFJ}}$ を下回ったものと考えられる。その 後, この割裂は合板表板繊維 $45^{\circ}$ 方向に進展し, 終 局破壊断面である集成材の材せい方向の LFJに沿 った割裂へと進展する。脆性破壊であったことから も， $\sigma_{\mathrm{FP}}$ が $\sigma_{0 \_\mathrm{LFJ}}$ を下回った理由としては，この割 裂の進展が一貫して生じたことによるとものと推察 する。この一連の破壊過程で, 合板表板繊維 $45^{\circ}$ 方 向に割裂が進展することから, 合板積層部材の表板

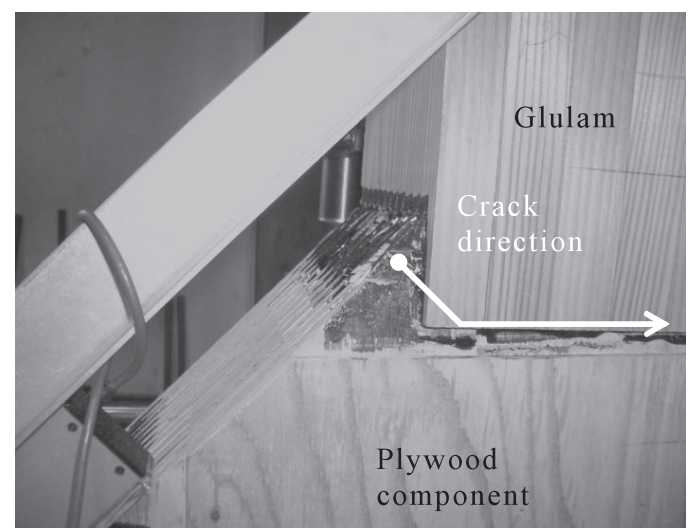

Fig. 11. Ultimate failure of $\mathrm{T}$-shaped specimen.

Note: The crack emanated at the void area of the plywood component of the opening mode side. The crack progressed in the 45 degree direction of the plywood component and consecutively into the finger root of the plywood component and toward glulam depth direction.
繊維方向を柱軸方向に揃えたとしても， $\sigma_{45 \_L F J}$ で設 計する必要があると考えられる。なお， $\sigma_{\mathrm{FP}}$ の $5 \%$ 下限值は $8.0 \mathrm{~N} / \mathrm{mm}^{2}$ で, $\sigma_{45 \_L F J}$ を下回るが, 個々の $\sigma_{\mathrm{FP}}$ はすべて $\sigma_{45_{-} \mathrm{LFJ}}$ を上回っていたことから， $\sigma_{45_{-} \mathrm{LFJ}}$ で設計する事は妥当であると判断する。

フィンガー未充足部の詳細な応力分布は, 有限要 素法などによる解析が望まれるが, 合板 $45^{\circ}$ 方向の ポアソン比は 0.5 を超える值 ${ }^{13)}$ であり, 解析断面を 設定する際には注意が必要である。したがって，本 報では，合板積層部材の表板繊維方向を柱軸方向に 一致させたとしても, 内隅最内皮では $45^{\circ}$ 方向で曲 げによる引張応力が発生しているものとし， $\sigma_{45 \_L F J}$ を根拠として設計許容耐力を設定すべきであると考 える。

\section{6 合板積層部材の耐力推定}

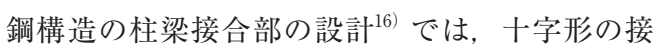
合部において，柱と梁で囲まれた部分（接合部パネ ル）を柱梁部材と独立して設計する方法が採用され ている。接合部パネルに作用するモーメント $M$ 品

$$
{ }_{\mathrm{p}} M={ }_{\mathrm{b}} M_{\mathrm{R}}+{ }_{\mathrm{b}} M_{\mathrm{L}}-\left({ }_{\mathrm{c}} Q_{\mathrm{U}}+{ }_{\mathrm{c}} Q_{\mathrm{L}}\right) \frac{d_{\mathrm{b}}}{2}
$$

ここで, ${ }_{\mathrm{b}} M_{\mathrm{R}},{ }_{\mathrm{b}} M_{\mathrm{L}}$ は接合部パネルの右および左 の梁端部に作用するモーメント， ${ }_{c} Q_{\mathrm{U}},{ }_{c} Q_{\mathrm{L}}$ は接合 部パネルの上および下の柱端部に作用するせん断 力, $d_{\mathrm{b}}$ は $\mathrm{H}$ 形鋼の梁フランジの板厚中心間距離で ある。一方, 接合部パネルのせん断変形をモーメン トとして表現した降伏モーメント ${ }_{\mathrm{p}} M_{\mathrm{y}}$ は (2) 式を用 いて算定される。

$$
{ }_{\mathrm{p}} M_{\mathrm{y}}=\frac{V_{\mathrm{e}}}{\kappa} \sqrt{1-n^{2}} \frac{F_{\mathrm{y}}}{\sqrt{3}}
$$

ここで, $V_{\mathrm{e}}$ は接合部パネルの有効体積, $\kappa$ はせ ん断に関する形状係数, $n$ は接合部パネルの軸力比 であり, $F_{\mathrm{y}} / \sqrt{3}$ は鋼材の降伏せん断強さである。

これら (1)，(2)式を本報の耐力推定式として適用 する。まず，本報の接合部パネルの内隅形状が特異 であることから, 中間部材のそれぞれの内隅中点で 
囲まれた部分でせん断変形が生じるものと仮定し た。Fig. 12に本接合部のせん断変形モデルを示す。

十字形の ${ }_{\mathrm{p}} M$ は, 左右の LFJ 部が同時に最大曲げ 応力に達した時とすると, LFJ 部の最大曲げモーメ ント $M_{\mathrm{LFJ}}={ }_{\mathrm{b}} M_{\mathrm{L}}={ }_{\mathrm{b}} M_{\mathrm{R}}$ であり, $M=\sigma \times Z$ の関係を 用いて, 梁幅 $b$, 梁せい $h$ として導くことができる。 ここで,（1）式の柱のせん断力の項は $M$ を る方向にあるため省略し, (3)式で表現する。

$$
{ }_{\mathrm{p}} M=M_{\mathrm{LFJ}}+M_{\mathrm{LFJ}}=\frac{b h^{2}}{3} \sigma_{\mathrm{LFJ}}
$$

$\mathrm{T}$ 字形, $\mathrm{L}$ 字形では ${ }_{\mathrm{b}} M_{\mathrm{R}}=0$ とすることで, (3) 式 の $1 / 2$ の值となる。

一方, ${ }_{\mathrm{p}} M_{\mathrm{y}}$ については, $V_{\mathrm{e}}$ は $b$ と Fig. $120 h_{\mathrm{b}}$, $h_{\mathrm{c}}$ に囲まれる体積であり， $\kappa$ は矩形断面では $3 / 2$ で ある。 $n$ は軸力を考慮しない場合の $n=0$ を代入す る。 $F_{\mathrm{y}} / \sqrt{3}$ は $\tau$ に相当する。以上より，(2)式は (4) 式となる。

$$
{ }_{\mathrm{p}} M_{\mathrm{y}}=\frac{2 b h_{\mathrm{b}} h_{\mathrm{c}}}{3} \tau
$$

ここで，柱と梁の部材断面は同じ場合に限定すれ ば, 十字形では $h_{\mathrm{b}}=h_{\mathrm{c}}=1.5 h, \mathrm{~T}$ 字形では $h_{\mathrm{b}}=1.5 h$, $h_{\mathrm{c}}=1.25 h$ であり, L 字形では $h_{\mathrm{b}}=h_{\mathrm{c}}=1.25 h$ である。

$\sigma_{\mathrm{LFJ}}$ と $\tau$ の組合せは中間部材の配置による。す なわち, 合板積層部材の表板繊維方向を $45^{\circ}$ 傾ける 場合は $\left(\sigma_{45 \_L F J}, \tau_{45}\right)$ とし, 一致させる場合には3.5 の結果を踏まえて $\left(\sigma_{45} \mathrm{LFF}, \quad \tau_{0}\right)$ を採用する。

以上より，(3) 式と(4) 式から ${ }_{\mathrm{p}} M$ と ${ }_{\mathrm{p}} M_{\mathrm{y}}$ の大小を 比較することで, LFJ 部の曲げ降伏が先行するか, 合板積層部材のせん断降伏が先行するかについて検
討する。Table 5 に，それぞれの条件での計算結果 を示す。 ${ }_{\mathrm{p}} M,{ }_{\mathrm{p}} M_{\mathrm{y}}$ の大小関係は, 十字形で合板積層 部材の表板繊維方向を軸方向に一致させた場合に ${ }_{\mathrm{p}} M_{\mathrm{y}}$ が小さく，その他は ${ }_{\mathrm{p}} M$ が大きかった。この大 小関係は, $b, h$ に依存しないことから, 中間部材 の形状が相似であり，合板積層部材の表板繊維方向 を柱軸方向に対して $45^{\circ}$ 傾けた場合には, LFJ 部の 破壊が先行するものと推定される。実大試験結果と の比較においても, ${ }_{\mathrm{p}} M_{\mathrm{y}}$ が $M_{\mathrm{FP}}$ を上回っていること からも, 接合部パネルは降伏しないものと考えられ, LFJ 部の曲げ強度で許容耐力を設定する妥当性が伺 える。

ただし，合板積層部材の表板繊維方向を柱軸方向 に一致させた場合には ${ }_{\mathrm{p}} M$ と ${ }_{\mathrm{p}} M_{\mathrm{y}}$ との差が小さい。

Table 5. Comparison with the yeild moment of LFJ and joint panel $(\mathrm{kN} \cdot \mathrm{m})$.

\begin{tabular}{ccccc}
\hline \hline \multirow{2}{*}{ Joint type $^{\text {a) }}$} & \multirow{2}{*}{ Angle $^{\mathrm{b})}$} & \multicolumn{2}{c}{ Estimated } & Observed \\
& & ${ }_{\mathrm{p}} M$ & ${ }_{\mathrm{p}} M_{\mathrm{y}}$ & $M_{\text {FP_5\%ile }}\left(M_{\text {FP_ave }}\right)$ \\
\hline \multirow{2}{*}{ Cross-shaped } & $0^{\circ}$ & 43.3 & 42.3 & - \\
& $45^{\circ}$ & 43.3 & 96.8 & - \\
\hline \multirow{2}{*}{ T-shaped } & $0^{\circ}$ & 21.6 & 35.3 & $18.0(33.1)$ \\
& $45^{\circ}$ & 21.6 & 80.7 & - \\
\hline \multirow{2}{*}{ L-shaped } & $0^{\circ}$ & 21.6 & 29.4 & - \\
& $45^{\circ}$ & 21.6 & 67.2 & $20.4(26.7)$ \\
\hline
\end{tabular}

a) : See Fig. 12 .

b) : Surface veneer's fiber direction of plywood component to beam axis.

c): Calculated with equation (3) and (4).

${ }^{d)}$ : Refer to Tables 3 and 4.

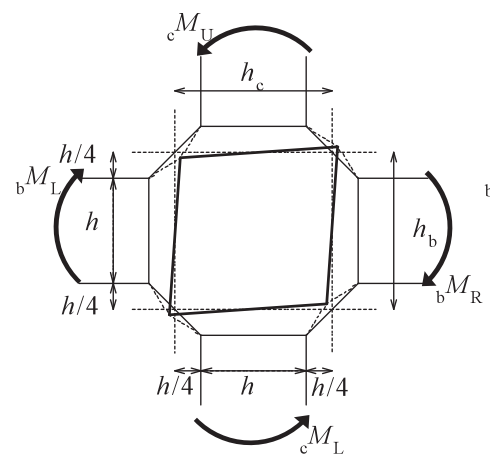

Cross-shaped

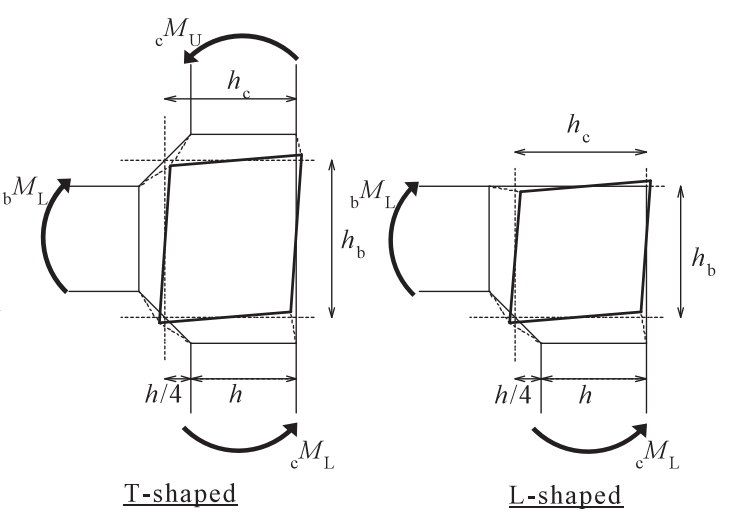

Fig. 12. Shear deformation model of the joint panel subjected to bending moment of the $\operatorname{beam}(\mathrm{s})$ and the definition of the available area $\left(h_{\mathrm{b}} \times h_{\mathrm{c}}\right)$.

Legend: ${ }_{\mathrm{b}} M_{\mathrm{L}},{ }_{\mathrm{b}} M_{\mathrm{R}}$ : Moment of the beam onto the joint panel to the left or the right, ${ }_{\mathrm{c}} M_{\mathrm{U}}$, ${ }_{c} M_{\mathrm{L}}$ : Moment of the column onto the joint panel to above or below, $h$ : Depth of the beam and column of the same value, $h_{\mathrm{b}}$ : Available depth of the joint panel on the beam side, $h_{\mathrm{c}}$ : Available depth of the joint panel on column side. 
この場合, ${ }_{\mathrm{p}} M$ と ${ }_{\mathrm{p}} M_{\mathrm{y}}$ は下限值であることから, 材 料強度のばらつきによって大小関係が逆転し, 終局 破壊性状が接合部パネルで起こる可能性がある。さ らに，実務設計では中間部材に梁受け金物などを取 り付ける加工が必至であることからも，確実にLFJ 部の曲げが終局破壊となるとは言えない。それゆえ に, 許容応力度設計に用いる場合には, 中間部材の 耐力を最大限確保する必要があり, 合板積層部材は 柱軸方向に対して $45^{\circ}$ 傾けることが望ましいと考え る。

以上より, 鋼構造の接合部パネルの降伏耐力推定 式を適用して評価した結果, 合板積層部材を $45^{\circ}$ 傾 けて配置した場合には，LFJ 部の曲げ強度が接合部 耐力を決定するものと考えられる。但し, 本報のよ うにフィンガー未充足部を有する場合には，ここで 初期破壊が発生して剛性が変化するため, このこと に配慮して設計耐力とする必要がある。

\section{4. 結論}

合板積層部材を中間部材としたラージフィンガー ジョイント接合部を対象として, 構成部材の材料強 度試験，ならびにL 字形， T字形の実大接合部試験 から, 以下の結論を得た。

・合板の表板繊維方向，もしくは表板繊維直交方向 の降伏ひずみは, 単純な引張力に由来するよりも, せん断力に由来する方が小さい。

· L 字形, T字形接合部の終局破壊は, LFJ 部にお ける合板積層部材側の曲げ破壊であるが，接合部 内隅のフィンガー未充足部で初期破壊が発生した ことにより，曲げ応力の比例限はいずれの仕様に おいても材料強度試験で得た曲げ強度を下回った。

・L字形接合部試験では, フィンガー未充足部の初 期破壊後は，延性的な破壊性状を示した。合板積 層部材の表板繊維方向を柱軸方向に対して $45^{\circ}$ 傾 けて配置していたことにより，初期割裂方向と終 局割裂方向が一致しなかったことによるものと考 えられ, 最大曲げ応力は材料強度試験で得た曲げ 強度を上回った。

・T字形接合部試験では, フィンガー未充足部の初 期破壊後は，脆性的な破壞性状を示した。合板積 層部材の表板繊維方向を柱軸方向と揃えて配置し たことにより，初期破壊から終局破壊までが一貫 して発生したことによるものと考えられ, 最大曲 げ応力は材料強度試験で得た曲げ強度には達しな かった。

-中間部材に本報と同形状で, 柱軸方向に対して $45^{\circ}$ 傾けた合板積層部材を用いる限りでは, 中間
部材を大きくした場合においても, 中間部材のせ ん断降伏よりも LFJ 部の曲げ破壊が先行するも のと考えられる。

・この場合の最大耐力は合板積層部材の $45^{\circ}$ 方向の 曲げ強度から, 比例限耐力はこれにフィンガー未 充足部の断面欠損を考慮することで推定すること が可能となるものと考えられる。

\section{謝辞}

本研究は, 科学研究費補助金 (若手研究 (A), 課題番号 : 17686048 , 代表 : 森 拓郎) の助成を受 けて実施した。また, 研究の遂行に当たって多くの 協力を頂きました川原重明氏（旧銘建工業(株),現株) 木質環境建築）ならびに清水武氏（同）に深く感謝 します。

\section{文献}

1）楠 寿博, 木村 衛, 室田達郎, 小松幸平, 鴽海 四郎：日本建築学会学術講演梗概集 構造 II, 東北, 1991, pp. 65-66.

2）楠 寿博, 木村 衛, 室田達郎, 小松幸平, 鴐海 四郎：日本建築学会学術講演梗概集 構造 II, 北陸, 1992, pp. 67-68.

3）木村 衛, 楠 寿博, 太田道彦：日本建築学会 構造系論文集 No. 480, 133-140（1996）。

4）財団法人日本住宅・木材技術センター：木造 化推進標準設計施工マニュアル作成等事業報 告 3 現場接着による集成材梁継手の開発報 告書, 9-45 (1992).

5）新田亜希, 小松幸平, 北守顕久, 川原重明：第 51 回日本木材学会大会研究発表要旨集, 東京, 2001, p. 181.

6) Nitta, A., Komatsu, K.: Wood Research No. 88, 56-57 (2001).

7) 坂田弘安, 岡田久志, 安部 裕, 楠 寿博, 伊東 洋路: 日本建築学会構造系論文集 No. 514, 163-168 (1998).

8）坂田弘安, 岡田久志, 安部 裕, 楠 寿博, 伊東 洋路：日本建築学会構造系論文集 No. 529, 121-126 (2000).

9）森 拓郎, 野田康信, 小松幸平：日本木材加工 技術協会第25回年次大会講演要旨集, 旭川, 2007, pp. 41-42.

10）野田康信, 森 拓郎, 小松幸平：第10回木質構 造研究会技術発表会技術報告集10，東京，2006， pp. $48-51$.

11）西田正孝：“応力集中増補版”, 森北出版, 東京, 
1973, pp. 114-122.

12）“合板の日本農林規格”, 農林水産省告示第 1751号 (2008).

13）高見 勇：林業試験場研究報告第225号, 41132 (1969).

14）堀江秀夫, 倉田久敬, 石井 誠：林産試験場研
究報告第76号, 45-71（1986）.

15）“木造建築物用接合金物認定事業における接合 金物試験法規格”, 財団法人日本住宅・木材技 術センター, 東京, 2011, p. 28.

16）“鋼構造接合部設計指針第 2 版”, 日本建築学 会編, 日本建築学会, 東京, 2006, pp. 206-214. 